\title{
The Study on the Personal Income Tax of the Policyholder Dividends and Its Impact on Chinese Insurance Industry
}

\author{
Wen Yan \\ School of Public Administration, Southwest Jiaotong University, Chengdu, China. \\ Email: sherrywen.001@163.com
}

Received 2013

\begin{abstract}
The policyholder dividend of participating insurance is essentially different from the usual equity and bond profit. There are disputes on taxing methods in theory and practice, and different countries adopt different taxing methods. This paper designs a basic framework of the personal income tax system on participating insurance policy. This policy is based on the reality that the participating insurance accounts for a higher proportion in the Chinese insurance market, which is conducive to increase the demand for insurance and the tax sources. The author believes that levying taxes is allowed, but there is no basis to tax on the total policyholder dividends, while tax on the part of policyholder dividends is reasonable. Finally, this paper analyzes the impact on the demand of life insurance industry and the total tax revenue to levy personal income tax on policyholder dividends. The author concludes that the taxing method designed in this paper is better than the taxing method levying tax on the total policyholder dividends.
\end{abstract}

Keywords: Income Tax; Policyholder Dividends; Chinese; Insurance; Industry

\section{Introduction}

Life insurance and tax are two important concepts in the modern economy; they display the social management functions both in the micro and macro economy. The relationship between life insurance and tax reflects that on one hand, the tax policy may encourage or inhibit the demand and supply to life insurance and on the other hand, the development of life insurance industry also affects the government's tax revenue to a certain extent.

As the leading product of the life insurance industry in China, since 2002, the proportion of participating insurance premium income in the total premium income of life insurance has been more than $50 \%$ for a long time. It was up to $57.09 \%$ in 2008 . Therefore, how to design a reasonable personal income tax system on the dividend income from participating insurance has a significant impact on the stable development of China's life insurance industry and even the insurance industry. The previous research in this area is mostly limited to the discussion of whether to levy tax, but lacks systematic study and plan design on the tax system. This paper designs a concrete plan on how to levy personal income tax on participating insurance in China; at the same time, the paper analyzes the possible impact and makes a empiri-

${ }^{1}$ IRS,2004, "Your Federal Income Tax" (for individuals for use in preparing 2004 returns), www.irs.gov. cal test on the impact.

\section{The Introduction of Personal Income Tax System on Policyholder Dividends from Participating Insurance}

By the analysis on the personal income tax system on policyholder dividends from participating insurance in the developed insurance market, the personal income tax system can be divided into two categories and four processing modes.

\subsection{Levying Personal Income Tax on Policyholder Dividends}

The first category is the levying personal income tax on policyholder dividends. This mode stipulates to exact personal income tax from policy holders within a certain range. In the practice of insurance tax, it may be divided into two modes according to the different calculations.

The first mode is the premium not be exempted from the taxable income. Take US and Canada as representatives. U.S. Internal Revenue Service defines the policyholder dividend as the part refund of premium paid by policy holders, which reduces the cost of policy holders, should not be included in income. ${ }^{1}$ So whether to tax depends on the total amount of policyholder dividends. If the total amount of policyholder dividends surpasses the 
net premium of insurance policy, the excess should be levied; on the contrary, it should not be taxed. Canada also regards the policyholder dividend as the part refund of premium paid by policy holders and its mode of tax collection is similar to that of the United States.

The second mode, the premium is exempted from the taxable income. Take Japan as representative. Unlike the United States, the Japanese tax law stipulates that the premium paid by the policy holders can be exempted from the taxable income, while the dividend is considered a return of premium. Therefore, in the calculation of taxable income, the policyholder dividends should be subtracted from the exemption premium, namely:

Taxable income $=$ the taxable income before insuring (the premium the policyholder dividends)

\subsection{Exempting from Personal Income Tax on Policyholder Dividends}

The second category: exempting from personal income tax on policyholder dividends. There are also two processing modes: First, take the United Kingdom as representative, its tax exemption was mainly determined by its special dividend distribution; ${ }^{2}$ Second, take Hong Kong and Singapore as representatives, they regard the whole policyholder dividends as a return of premium, therefore the policyholder dividends are completely tax-free.

\section{The Tax System Designed on the Policyholder Dividends of the Participating Insurance in China}

In view of current contradictions and problems in participating insurance business and tax collection, I believe that we should proceed in two aspects: One is whether we should levy tax? Another is how to design the basic framework of the tax system?

A) on the question of whether should levy tax, the viewpoint of this paper is that levying tax is allowed, but there is no basis to levy tax on the total policyholder dividends, while levy tax on the part of policyholder dividends is reasonable. The reasons are as follows:

- $\quad$ First, from the view of the nature of policyholder dividends, it has a dual nature, that is, it is composed of the premium return and investment income. Policyholder dividends derives from three benefits(the benefit from the actual mortality is lower than the hypothetical mortality, the benefit from the actual investment rate is higher than the hypothetical investment rate, the benefit from the actual expenses rate is lower than the hypothetical expenses rate), the benefit from the actual

\footnotetext{
${ }^{2}$ Unlike the United States, Canada and Japan, policyholder dividends are usually added to the insurance amount in England, therefore the policyholder dividends is tax-free.
}

mortality is lower than the hypothetical mortality and the benefit from the actual expenses rate is lower than the hypothetical expenses rate can be viewed as the return of premium, because they come from the cautious pricing of insurance companies. while the benefit from the actual investment rate is higher than the hypothetical investment rate cannot be treated as a return of premium, because the buying behavior of the policy holders should be regarded as an endorsement of the hypothetical rate, therefore the benefit from the actual investment rate is higher than the hypothetical investment rate should be regarded as the benefit of insurance company investment, namely it should be treated as investment income of policy holders.

- Second, from the view of the functions of participating insurance, the safeguard function of participating insurance has replaced the social function of the national finances to some extent, therefore there should be granted a tax exemption for the safeguard part of participating insurance, while we should levy tax on the investment part of participating insurance.

- Third, from the view of insurance premium structure of participating insurance, the investment part can be regarded as non-voting shares ${ }^{3}$ of the insurance company, so it should be levied personal income tax according to the existing personal income tax law.

- $\quad$ Fourth, from the perspective of cumulated policyholder dividends and foreign experience, , the excess should be levied tax when the cumulated policyholder dividends exceed the cost of insurance, such as the U.S., Canada, Japan and so on.

B) The basic framework of the personal income tax system on participating insurance policy in China

The personal income tax system on participating insurance must follow the principles of fairness and efficiency, it cannot lose a tax should be levied. At the same time; we should try to avoid the impact of taxation on the life insurance market. By learning from foreign experience and following the operating characteristics of the life insurance industry, the basic framework of the personal income tax system on participating insurance in china includes the following four aspects:

- First, the tax source and the tax base. the tax source and the tax base of participating insurance include three benefits (the benefit from the actual mortality is lower than the hypothetical mortality,

\footnotetext{
${ }^{3}$ Nonvoting shares refers to the shares which does not entitle the holders the right to operate and manage the Corporation according to the laws or the company's Charter, but the shareholders can still participate in the general meeting.
} 
the benefit from the actual investment rate is higher than the hypothetical investment rate, the benefit from the actual expenses rate is lower than the hypothetical expenses rate) as well as the accumulated interest of policyholder dividends. In the situation that the accumulated interest of policyholder dividends is less than the policy cost, the benefit from the actual mortality is lower than the hypothetical mortality and the benefit from the actual expenses rate is lower than the hypothetical expenses rate included in policyholder dividends are completely tax-free, while for the benefit from the actual investment rate is higher than the hypothetical investment rate in the policyholder dividends should be levied tax, the accumulated interest of policyholder dividends should also be levied tax;

- Second, the taxing method. The personal income tax system on participating insurance adopts taxdeferred $^{4}$ withholding 5 taxing method, the taxation time point has been deferred the end of the policy period. This method not only saves the administrative cost, but also produces a incentive effect on policyholders.

- Third, the determination of the tax rate. Due to the social management function of life insurance industry, certain preferential taxation should be reflected in the tax rate determining. This paper proposes the preferential tax rate is set at $10 \%$;

- Fourth, the implementation time of the personal income tax system on participating insurance .Be consistent with other investment products, it should be introduced at the right moment.

\section{The Analysis of the Impact on Life Insurance Industry to Levy Personal Income tax on Policyholder Dividends}

A) The economic analysis of the impact on the life insurance industry to levy personal income tax on policyholder dividends

Levying personal income tax on policyholder dividends will undoubtedly affect the life insurance demand. Currently, the main motivation for participating insurance policyholders is to obtain an investment return which should be higher than the market average investment rate. The impact path of taxation on the life insurance demand are that levying personal income tax on policyholder dividends leads to the decline in expected return rate of policyholders. On the one hand, compared

\footnotetext{
${ }^{4}$ Deferred taxing method means a tax policy that the taxpayers will pay the tax after obtaining an income.

${ }^{5}$ Withholding taxing method means the tax amount shall be withheld and paid to the tax authorities by the enterprises and individuals obligated to pay tax according to the tax law from the taxpayer's income.
}

with other investment products, the participating insurance becomes more expensive; on the other hand, the actual income of the participating insurance policyholders declines. Rising relative price and falling real income make participating insurance policyholders turn to other financial products as an alternative. The above lead the overall decline in the life insurance demand. Specific shown in Figure 1:

In Figure 1, the $x$-axis represents the participating insurance demand; the $\mathrm{y}$-axis represents the demand to other investment-oriented financial products, the line-AX and the line-AN represent separately the Pre-tax and Post-tax budget lines while the income stays at the same level. Before levying on policyholder dividends, the demand of the participating insurance is $\mathrm{x} 3$ when the budget line-AX is tangent to the Difference Curve in the Demand - U1. After levying on policyholder dividends, the demand of the participating insurance is $\mathrm{x} 1$ when the budget line-AN is tangent to the Difference Curve in the Demand - U2. In the Figure, the distance between X2 and $\mathrm{X} 1$ represents the demand reduction to the participating insurance. The reason leading to the reduction is that the rising relative price of the participating insurance makes the policyholders turn to other alternative investment products, which is the substitution effect. Likewise, the distance between $\mathrm{X} 2$ and $\mathrm{X} 3$ represents the demand reduction to the participating insurance, while the reason leading to the reduction is that the rising relative price of the participating insurance causes the decline in actual income, which is the income effect. The distance between X1 and X3 aggregating the substitution effect and the income effect is the demand reduction to the participating insurance caused by the introduction of the personal income tax on policyholder dividends.

B) The empirical analysis of the impact on the life insurance industry to levy personal income tax on policyholder dividends

On the difference between the tax system of participating insurance designed by this paper and the tax system stipulated by the tax authorities, we will analyze their impact on the life insurance industry and the total tax revenue next:

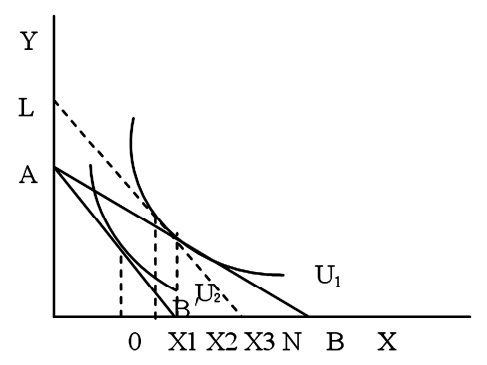

Figure 1. the income effect and the substitution effect of levying personal income tax on policyholder dividends to participating insurance. 


\section{1) Data selection}

This paper takes the proportion of participating insurance premium income in the total homochronous life insurance premium income as the output variable, and takes the investment rate as input variable. For the policyholders purchased participating insurance, their participating insurance investment rate is based on that of the previous year, which means, if they buy the participating insurance in period $\mathrm{T}$, they will refer to investment rate in period $\mathrm{T}-1$. This paper selects the proportion of participating insurance premium income in the total homochronous life insurance premium income for the year of 2001-2008 and insurance fund investment rate for the year of 2000-2007 in China as the sample data, as shown in Table 1:

2) Research methods

This paper adopts the output contribution ratio to the input to analyze the relationship between the proportion of participating insurance and investment rate. The contribution ratio is an indicator of analyzing the economic efficiency. It refers to the ratio of the effective or useful results and the resource consumption or occupancy, namely the ratio of the output and the input, or the ratio of the obtained and the consumption. The formula is:

Contribution ratio $(\%)=$ Contribution (output, the obtained)/Input (consumption, occupancy) $\times 100 \%(2)$

This paper will take the investment rate as the input, and take the proportion of participating insurance premium income in the total homochronous life insurance premium income as the contribution. The Contribution ratio that the investment rate to the proportion of participating insurance premium income refers to the proportion of participating insurance premium income in the

Table 1. the development situation of participating insurance for year of 2001-2008 and insurance fund investment rate for the year of 2000-2007 in China.

\begin{tabular}{cccc}
\hline $\begin{array}{c}\text { Period } \\
\text { T }\end{array}$ & $\begin{array}{c}\text { the proportion of } \\
\text { participating insurance } \\
\text { premium income in the } \\
\text { total homochronous life } \\
\text { insurance premium } \\
\text { Income (\%) }\end{array}$ & $\begin{array}{c}\text { Period } \\
\text { T-1 }\end{array}$ & $\begin{array}{c}\text { investment } \\
\text { rate of } \\
\text { insurance } \\
\text { fund (\%) }\end{array}$ \\
\hline 2001 & 36.64 & 2000 & 3.59 \\
2002 & 49.3 & 2001 & 4.3 \\
2003 & 57.84 & 2002 & 3.14 \\
2004 & 56.54 & 2003 & 2.68 \\
2005 & 56.89 & 2004 & 2.9 \\
2006 & 59.37 & 2005 & 3.6 \\
2007 & 49.76 & 2006 & 5.8 \\
\hline 2008 & 57.06 & 2007 & 12.17 \\
\hline
\end{tabular}

total homochronous life insurance premium income corresponding to per unit of investment rate. Under the assumption that the contribution ratio of the participating insurance is $\gamma_{T}$ in period $\mathrm{T}$, the proportion of participating insurance premium income in the total homochronous life insurance premium income is $y_{T}$ in pe$\operatorname{riod} \mathrm{T}$, the investment rate is $\chi_{T-1}$ in period T-1, that is:

the proportion of participating insurance premium income in the $\gamma_{T}=\frac{\text { total homochronous life insurance premium income in period } \mathrm{T}}{\text { the investment rate in period } \mathrm{T}-1}$ $=\frac{y_{T}}{\chi_{T-1}}$

3) Data analysis

According to Equation(3) and the data in Table 1, the contribution ratio that the participating insurance to the investment rate in China for the year of 2001-2008 can be obtained. It is shown in Table 2:

Table 2 shows that during 2004to 2008, the contribution ratio that the participating insurance to the investment rate in China has been rising rapidly, while in 2004-2008, the contribution ratio came down gradually. The reason is that from 2001 to 2004, the capital market in china has been in a bear market over a long period of time. There are not many other investment products in the financial market, while the dividend rates of the participating insurance were much higher than the homochronous bank deposit interest rate. So the participating insurance got a rapid development. From 2001 to 2004, the capital market became active gradually; lots of investment products began to emerge. During this time, the stimulating effect of the dividend rates to participating insurance demand decreased gradually.

Table 2. the contribution ratio of the investment rate in China for the year of 2001-2008.

\begin{tabular}{ccccc}
\hline Period & $\begin{array}{c}\text { the proportion of } \\
\text { participating insurance } \\
\text { premium income in the } \\
\text { total homochronous life } \\
\text { insurance premium } \\
\text { income (\%) }\end{array}$ & $\begin{array}{c}\text { Period } \\
\text { T-1 }\end{array}$ & $\begin{array}{c}\text { The } \\
\text { Investment } \\
\text { Rate (\%) }\end{array}$ & $\begin{array}{c}\text { The } \\
\text { contribution } \\
\text { ratio of the } \\
\text { investment } \\
\text { rate (\%) }\end{array}$ \\
\hline 2001 & 36.64 & 2000 & 3.59 & 10.21 \\
2002 & 49.3 & 2001 & 4.3 & 11.47 \\
2003 & 57.84 & 2002 & 3.14 & 18.42 \\
2004 & 56.54 & 2003 & 2.68 & 21.10 \\
2005 & 56.89 & 2004 & 2.9 & 19.62 \\
2006 & 59.37 & 2005 & 3.6 & 16.49 \\
2007 & 49.76 & 2006 & 5.8 & 8.58 \\
2008 & 57.06 & 2007 & 12.17 & 4.69 \\
Average & 52.925 & & 4.7725 & 13.82 \\
\hline
\end{tabular}


Dividends rate is $5 \%$, the personal income tax rate is $10 \%$ on policyholder dividends, the market interest rate is 0 , the extra policy dividends more than the insurance cost accounts for $80 \%$. According to the calculation formula of the contribution ratio, this paper selects the average contribution ratio between 2005 and 2008 as a reference point to the impact degree of the participating insurance, which is 12.35.Take 2007 as the example:

First, let us analyze the tax system stipulated by the tax authorities. The total Post-tax policyholder dividend is $400 * 5 \% *(1-10 \%) * 10=180$ Billion Yuan; Taxable personal income amounts to $400 * 5 \% * 10 \% * 10=20$ Billion Yuan. After the taxation, the proportion of participating insurance premium income in the total homochronous life insurance premium income refers to $49.76 \%$ $5.8 * 10 \% * 12.35=42.6 \%$, dropping by $(5.8 * 10 \% * 12.35$ $149.76 \%) * 100 \%=14.39 \%$. After the taxation, the premium income of the life insurance industry drops by $(5.8 * 10 \% * 12.35 / 49.76 \%) * 49.76 \%=7.16 \%$.

Second, we design the tax system of participating insurance designed by this paper. The viewpoint in this paper is that the tax-deferred withholding taxing method should be adopted to levy personal income tax on the policyholder dividends. The tax scope includes the extra policyholder dividends more than the insurance cost and the accumulated interest of policyholder dividends. Therefore, at the expiry time of insurance policy, the policyholder dividends and interest amounts to $400 * 5 \%$ *

$$
\frac{\left(1-1.05^{10}\right)}{1-1.05}=251.56
$$

billion Yuan, of which the policyholder dividends is 20 billion Yuan, and the accumulated interest is 5.156 billion Yuan. Taxable personal income tax totals $200 *$ $80 \% * 10 \%+51.56 * 10 \%=2.116$ billion Yuan, an increase of 116 million Yuan more than the original. After the taxation, the total policyholder dividends is $251.56-21.56=23$ billion Yuan, the policyholder dividends rate is $5.75 \%$, the proportion of participating insurance premium income in the total homochronous life insurance premium income refers to

$$
49.76 \%-5.8 *(5-5.75) / 5 * 12.35=60.50 \%,
$$

increasing by $10.74 \%$. After the taxation, the premium income of the life insurance industry increases by $10.74 \% * 49.76 \%=5.35 \%$.

\section{Conclusions and Suggestions}

This paper has made theoretical and empirical analysis on the question whether personal income tax should be levied on the policyholder dividends of participating insurance. By contrast, we conclude that if levying $10 \%$ personal income tax on the policyholder dividends of the participating insurance in accordance with the claims of the tax authorities, the market share of the participating insurance will drop by $14.39 \%$, as well as the premium income of the participating insurance will decreases by $7.16 \%$. Following the recommendations in this paper, whether to levy personal income tax depends on the different sources of policyholder dividends. On one hand, the market share and premium income of the participating insurance will increase; on the other hand, the tax revenue of tax authorities also increases. The viewpoint in this paper is that the tax-deferred withholding taxing method should be adopted to levy personal income tax on the policyholder dividends, compared with the claim of the tax authorities. This taxing method has a strong advantage both on policy benefit of policyholders and on the total tax revenue of tax authorities.

In short, there will be a greater negative impact on the development of life insurance industry undoubtedly to levy personal income tax on the policyholder dividends of the participating insurance. However we can minimize the negative impact through designing reasonable tax system, even the negative impact can be transformed into a positive impact, and make the participating insurance business develop healthily.

\section{REFERENCES}

[1] Li Guodong.Shall Individual Income Taxes be Paid on Dividends from Participating Policy? [J]. Foreign tax,2006,No.9, 33-36.

[2] Wang Han, Gu Yi. The characteristics and the tax system improvement of new life insurance products in China[J]. Accounting Communications, 2007, 6, 23-24.

[3] Wang Han. the study on perfecting the tax system of new life insurance in China[J]. Shenzhen finance, 2007, 11, 29-31.

[4] Liu Di. The innovation on insurance products challenges existing insurance tax system [J]. Shanghai Finance, 2004, 11, 13-15.

[5] Wang Yanbin. The study of levying personal tax on the participating insurance [J]. Shanghai Finance, 2006 ,3, 14-16.

[6] Deng Yunan. The impact of insurance tax system on insurance product innovation [D]. Chengdu: finance department of Southwest University of finance and economics, 2006.

[7] OECD,2001, “ Taxing Insurance Companies” ,OECD Tax Policies Studies No.3, the Chinese name is called The internal target management and tax management in insurance company (not published).

[8] IRS,2004, “Your Federal Income Tax” (for individuals for use in preparing 2004 returns), www.irs.gov

[9] Harold D. Skipper Jr., 2001, “The Taxation of Life Insurance Policies in OECD countries: Implications for Tax Policy and Planning” , www.oecd.org/daf/insurance-pensions/ 
[10] Establishing Life Insurance Tax Policy in Developing Countries. UNCTAD (United Nations Conference on Trade and Development) . 1985

[11] Swiss Reinsurance Company. A Comparison of Social and Private Insurance, 1970-1985, in Ten Countries, Sigma, Swiss Reinsurance Co., Zurich. (1987).

[12] Seiichi Kondo.Insurance and Private Pensions Compendium for Emerging Economies (2002), OECD, Paris.

[13] OECD (1999). Report on the conference on insurance regulation and supervision in Asia (Singapore,1-2 February 1999), OECD, Paris.

[14] Goshay. Robert.Net Income as a Base for Life Insurance Company Taxation in California: Implications.1976. Journal Of Risk and Insurance. 1976.

[15] Gupta.K Newberry.Determinants of the Variability in Corporate Effective Tax Rates:Evidence from Longitudinal Data. Journal of Accountancy. 1997. 